\title{
EMPLOYER OF LAST RESORT FOR THE CZECH REPUBLIC
}

\section{Filip Červenkaa iD}

\begin{abstract}
This article simulates a programme called Employer of Last Resort, and analyses its potential impact in the Czech Republic.

The design of the programme guarantees perfectly inelastic demand for labour at a given wage level. In practice, the state would offer a job to anyone willing to work in order to eliminate involuntary unemployment, reduce poverty and income inequality and secure stable growth. My aim is to estimate hypothetical effects on the main objectives and calculate fiscal demands if the programme was launched on the Czech labour market.

The results suggest that the programme could significantly reduce unemployment and decrease income inequality. On the other hand, it would have limited impact on income poverty.

The gross wage costs of implementing the Employer of Last Resort programme in the Czech Republic are in all constructed scenarios below 1\% of the gross domestic product and further calculations suggest that the total net costs could even be negative.
\end{abstract}

Keywords: Employer of Last Resort, unemployment, income inequality, poverty JEL Classification: E12, E24, H55

\section{Introduction}

In 2020, an epidemic of COVID-19 struck countries across the globe. The situation still persists at the time of writing, causing a heavy crisis of both healthcare and economic systems. Governments face a challenge that is unprecedented in modern history.

To deal with the economic and social consequences of the epidemic, policymakers seek new and innovative solutions. One such solution could be a post-Keynesian macroeconomic tool called Employer of Last Resort (ELR). In this study I analyse the programme as an instrument for reducing unemployment, income inequality and poverty and calculate its fiscal costs not just in response to the COVID-19 crisis, but as a long-term systematic solution.

\footnotetext{
* This research was funded by funding for specific research at the Masaryk University, Faculty of Economics and Administration, project MUNI/A/1451/2020. This support is gratefully acknowledged.

a Masaryk University, Faculty of Economics and Administration, Brno, Czech Republic Email: filip.cervenka@post.cz
} 
Section 2 presents the theory: it summarizes the goals and basic characteristics of the programme, describes similar studies from abroad and also briefly discusses criticism related to ELR. Section 3 shows data and explains methods used. Data are gained predominantly from public sources, extended with data from a survey performed that focused on willingness of potential participants to enter the programme under various circumstances (later used in differentiated scenarios). The final part presents the results: potential impact of ELR on employment and state budget, net costs of ELR, and potential effect on poverty and income inequality. The main findings are then summarised in the conclusion section.

\section{Theoretical Background}

ELR is aimed towards labour markets similarly as central banks are aimed towards the financial and banking sector, which means that ELR would offer vacancies for "lower than the market wage". This chapter describes the theory behind it.

\subsection{Goals of ELR}

The theoretical framework for the "Employer of Last Resort" tool was first properly introduced by Hyman Minsky in the 1960s (Minsky, 1965) and its original goal was poverty reduction. Although the basic framework was designed more than 50 years ago, most studies on this topic were written in the late 1990s and later, after the 2008 financial crisis.

In recent literature, the target areas are quite wide. The most frequently declared goal of ELR is full employment, together with GDP growth, reduction of income inequality and poverty (Wray, 2009).

According to Kregel (2009), ELR could help meet many of United Nations Millennium Development Goals, as enhancement of developing countries or gender equality.

The ELR scheme is also investigated as an instrument for environmental goals. Godin (2012) argues that ELR would help reach the Kyoto Protocol objectives and reduce carbon dioxide emissions through newly created "green jobs".

\subsection{Characteristics and settings of ELR programme}

Objectives pursued have naturally changed since the introduction of the programme. On the other hand, all the important features have remained basically the same since Minsky first described it.

The programme is built on three main characteristics (Mastromatteo and Esposito, 2017), namely: 
1) ELR offers employment to all who are willing to work for a given wage,

2) ELR wage is lower than the market wage,

3) ELR fulfils local social and environmental projects.

In practice, a special evaluation commission would be established to choose projects which should be implemented. Local municipal authorities could be suitable for this function, or a new institution could be founded. Potential applicants would be generally offered jobs such as maintenance of public infrastructure, assistants in libraries or museums, support workers in hospitals or facilities for pensioners, or assistants in a wide range of other social or environmental projects (Antonopoulos et al., 2014).

Those who would agree to enter the ELR programme would be regular employees with all legal rights and duties related to such a position and all would receive an identical "ELR" wage. Such a wage (as an opportunity available to all economically active persons) would become a comparative base for other alternatives. Therefore, the programme would de facto set a new level of minimum wage (Mastromatteo and Esposito, 2017).

\subsection{ELR in different countries}

The aim of my study is to assess potential costs and benefits of implementing the ELR programme in the Czech Republic. I base my research on findings from three studies focusing on Greece, Italy (hypothetical works) and Argentina (real implementation).

ELR has also been applied in India, Chile and South Korea (Wray, 2007), and some of the ELR characteristics could be recognized in public policies in other countries, as for example Czech community works. However; due to violation of some basic characteristic or lack of data, these were not included in this study, and I continue only with the ELR in Greece, Italy and Argentina.

The Greek study creates four scenarios, which differ in numbers of participants and in setting of the minimum (ELR) wage. The programme could employ from 200 to 550 thousand participants and the total costs of implementing it would amount to 1.6-5.4\% of the Greek GDP. This sum represents the "gross" costs, but the "net" costs could be significantly lower, as we may consequently expect multiplication effects, enhancement of GDP growth and higher tax revenues (Antonopoulos et al., 2014).

A similar simulation was calculated for the Italian labour market. In Italy, the ELR wage would be set at a level of 12,000 euros per year and total employment within this scheme would be approximately 1.7 million people. The expected impact on the Italian state budget shows the gross costs of ELR to be only $2 \%$ of the GDP and the net costs of the ELR programme to be negative. The government budget would gain 2.3 billion euros per year (Mastromatteo and Esposito, 2017). 
In contrast to studies for Greece and Italy, which are purely theoretical, the programme was launched in Argentina in 2002. The outcomes were monitored and evaluated by Wray and Tcherneva (2005).

The programme called "Jefes" (with some reservation) fulfils the characteristics of an ELR scheme. In Argentina, almost 2 million inhabitants took part in it, which amounts for more than $5 \%$ of the total population. The wage was set at a level of 150 pesos per month and the total costs were 1\% of Argentina's GDP (Wray and Tcherneva, 2005).

The basic outcomes of the Argentinian "Jefes" programme are close to those from the Greek and Italian theoretical ELR models. Table 1 summarizes the outcomes of all the presented studies.

Table 1: ELR programme in different countries

\begin{tabular}{l|l|r|r|r|c}
\hline Year & Country & Participants & Monthly wage & \multicolumn{1}{c|}{ Wage (CZK) } & Gross cost (GDP) \\
\hline $\mathbf{2 0 1 4}$ & Greece & $200-550 k$ & $586-751$ EUR & $16,100-20,700$ & $1.5-5.4 \%$ \\
\hline $\mathbf{2 0 1 7}$ & Italy & $1,700 k$ & 1,000 EUR & 27,200 & $2 \%$ \\
\hline $\mathbf{2 0 0 2}$ & Argentina & $2,000 k$ & 150 ARS* & 1,800 & $1 \%$ \\
\hline
\end{tabular}

Note: * Argentine peso

Source: Author's summarization of cited studies

\subsection{Controversy around ELR}

Many authors emphasize that ELR could be a suitable answer to several economic and social issues. On the other hand, it is naturally not without potential risks.

The opponents of ELR frequently argue that it produces jobs with low productivity, it yields inflation, or that it is costly. These and other critics are reviewed by Mastromatteo and Esposito (2017). They defend the productivity of ELR jobs with the fact that the possible low productivity of ELR jobs is better than no productivity at all (which is what can be expected from unemployed persons).

They also argue that ELR can actually be a factor stabilizing prices and it anchors inflation expectations, as the ELR wage "is not linked to the balance of forces in each sector, nor to short-term profitability and investment, so it helps stabilize the labour market".

The objections related to the costs of ELR can be answered with several studies which conclude otherwise, as those cited above (Wray and Tcherneva, 2005; Mastromatteo and Esposito, 2017; Antonopoulos et al., 2014), and the calculation of ELR costs is also one of the main objectives of this study, and they will be investigated in the following sections. 


\section{Methods and Data}

To calculate the potential impact of the ELR scheme, I run a historic simulation. I use data from the Czech Labour Office from 1995 to 2018 to gain the total pool of unemployed persons and, furthermore, I use a survey to estimate what portion of them could take part in the programme. As the simulated ELR wage, I use the legal minimum wage valid in each year.

Calculations in this study are inspired by calculation for the Greek labour market, which distinguishes between several different scenarios (Antonopoulos et al., 2014). I find this way of calculation appropriate, due to the high level of uncertainty related to specific aspects of labour conditions, characteristics of chosen projects, or predominant public opinion on ELR.

For the Czech Republic, I suggest three scenarios: moderate, medium and extensive. As in the Greek study, these scenarios differ in numbers of participants. In addition, they are distinguished by specific circumstances affecting potential employees' decision whether to enter the programme. In each case, the circumstances defining the scenarios have its economic justification and were chosen due to its macroeconomic importance, data availability and interpretability.

Scenario 1: moderate participation

In the first scenario, the total number of employees is low. I assume that people are only willing to take part in ELR if there is a severe economic downturn accompanied by high rates of unemployment. In other words, I assume that if ELR was not popular, it could remove only cyclical unemployment.

Scenario 2: medium participation

In the second scenario, ELR would cover not only cyclical unemployment, but also long-term unemployment. I see this assumption as quite convenient based on three arguments. Firstly, long-term unemployment partially includes both cyclical and structural unemployment. Secondly, long-term unemployment is a serious socio-economic and political issue. And finally, there are accessible, transparent and valid data on this matter.

Scenario 3: extensive participation

The final scenario represents an assumption of maximum possible participation. In this hypothetical case, all persons registered at the Labour Office (all persons publicly declaring that they seek an occupation) would enter the ELR programme. This scenario gives us the upper limit of participants and the upper limit for hypothetical fiscal demands. 
In practice, I calculate what portion of unemployed persons belongs to long-term unemployment and cyclical unemployment to get information about potential ELR participants. Using the minimum wage as the predicted ELR wage, I estimate potential costs of the programme. Scenarios differentiated by realistic circumstances allow including information on potential participants' willingness to enter ELR in different situations.

Therefore, in the next part, I repeat the calculations for all the scenarios using data from the survey performed. Its outcomes are described in the following section.

\subsection{Survey on ELR in the Czech Republic}

The survey was processed during 16 days in the period from 2 to 18 March 2019 and it was conducted in direct relation to this research.

It was spread through social media with paid promotion, which ensured that the survey was displayed to more than 20,000 randomly selected users, limited by two conditions: living in the Czech Republic and being of productive age. In total, 785 respondents took part in it. The structure of the respondents consisted of 57\% women and $43 \%$ men with an average age of 34 years.

Most respondents were employees (54\%), followed by economically inactive - students, maternity leaves, etc. (24\%), entrepreneurs and self-employed persons (10\%) and unemployed persons $(5 \%)$.

The respondents lived predominantly in large cities over 100 thousand inhabitants (44\%), followed by respondents living in towns between 5 and 100 thousand inhabitants (33\%), and respondents from small towns and settlements under 2 thousand inhabitants $(16 \%)$.

\section{Figure 1: Entering ELR in three different scenarios: survey outcomes}

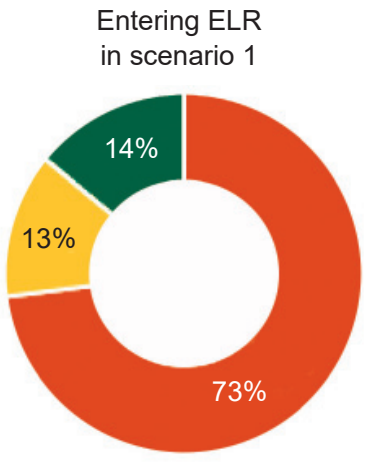

Yes / rather yes
Entering ELR in scenario 2

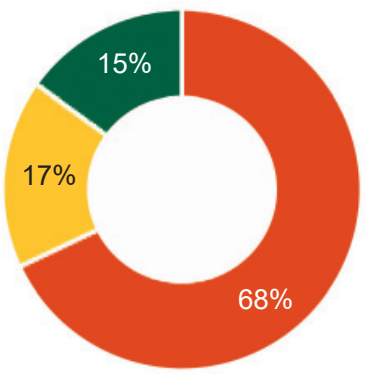

No / rather no
Entering ELR

in scenario 3

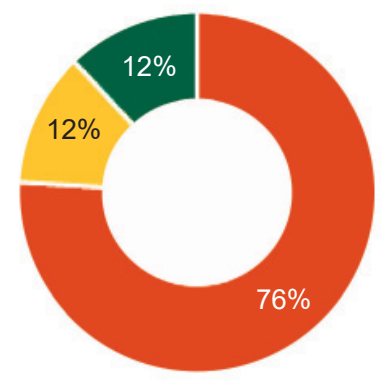

Cannot answer

Source: Outcomes from author's survey 
In each case, respondents were asked if they would enter the ELR programme under given circumstances. The first question was directed towards a situation where respondents would be unable to find a job because of severe economic crisis. Data gained from this question helps construct the model Scenario 1 (moderate participation).

Similarly, the second question asked the same in case that respondents would be unable to find a job for a period longer than 12 months. These data complete the model Scenario 2 (medium participation).

The final question was different from the others. Respondents were asked if they would be willing to enter the ELR programme under unspecified pressing personal/family/ economic conditions. This last question was general.

In all cases, most respondents expressed their willingness to enter the ELR programme. There were $73 \%$ of affirmative answers in the case of economic crises, $68 \%$ in the case of experiencing long-term unemployment and $76 \%$ generally.

The rate of affirmative questions was very similar across all socio-demographic groups with only one exception. Entrepreneurs and self-employed were more reserved, but even within this group the willingness to enter ELR was above $55 \%$ in all scenarios.

Such results are surprisingly high, considering the situation in which the survey was processed. At the time of conducting the survey, the Czech unemployment rate was just 2\% (MoLSA, 2020).

\section{Employment and Total Wage Costs}

To execute the calculations, I gathered data from several sources. Data on unemployment come from the Czech Ministry of Labour and Social Affairs and represents the number of persons registered at Labour Offices (MoLSA, 2021a). ${ }^{1}$ Apart from that, I use data from a labour force survey (hereafter "LFS") in order to calculate cyclical unemployment (CZSO, 2020). Also, data from OECD databases on long-term unemployment are incorporated (OECD, 2019). Finally, other indicators, which serve for relative comparison (such as Czech GDP and state budget), are obtained from the website of the Czech Ministry of Finance (MoF, 2019).

The results are divided into two groups. The first group stands for the three scenarios without incorporating the survey results, and the second group includes them.

1 Original data are monthly numbers of applicants at Labour Offices. For the purpose of this study, the data were averaged annually. "Unemployment" can therefore be interpreted as the average number of unemployed persons (registered in the Labour Office database) in a given year. 


\subsection{Simple simulation}

The following calculation is a simulation of ELR under different circumstances. I start from the real numbers of unemployed persons in the period 1995-2018. The scenarios differ in the portion of unemployed persons that would enter ELR. Based on these numbers of hypothetical ELR employees, I derive total wage costs in Czech crowns, wage costs as a percentage of GDP and wage costs as a percentage of the state budget.

Table 2: Estimation of ELR participants (without using survey data)

\begin{tabular}{|c|c|c|c|c|}
\hline Year & $\begin{array}{c}\text { Total } \\
\text { unemployed }\end{array}$ & $\begin{array}{c}\text { ELR participants: } \\
\text { Scenario } 1\end{array}$ & $\begin{array}{c}\text { ELR participants: } \\
\text { Scenario } 2\end{array}$ & $\begin{array}{c}\text { ELR participants: } \\
\text { Scenario } 3\end{array}$ \\
\hline 1995 & 154,992 & 0 & 48,303 & 154,992 \\
\hline 1996 & 162,042 & 0 & 50,640 & 162,042 \\
\hline 1997 & 222,983 & 0 & 68,081 & 222,983 \\
\hline 1998 & 316,567 & 0 & 98,876 & 316,567 \\
\hline 1999 & 447,367 & 46,395 & 165,962 & 447,367 \\
\hline 2000 & 468,708 & 70,202 & 228,580 & 468,708 \\
\hline 2001 & 444,017 & 48,596 & 234,178 & 444,017 \\
\hline 2002 & 479,650 & 84,759 & 243,330 & 479,650 \\
\hline 2003 & 522,758 & 128,385 & 260,998 & 522,758 \\
\hline 2004 & 537,398 & 143,012 & 278,489 & 537,398 \\
\hline 2005 & 513,007 & 115,419 & 274,885 & 513,007 \\
\hline 2006 & 472,212 & 72,688 & 260,681 & 472,212 \\
\hline 2007 & 388,875 & 0 & 207,602 & 388,875 \\
\hline 2008 & 324,465 & 0 & 162,924 & 324,465 \\
\hline 2009 & 473,363 & 67,146 & 147,541 & 473,363 \\
\hline 2010 & 529,684 & 124,817 & 229,515 & 529,684 \\
\hline 2011 & 505,567 & 102,192 & 210,121 & 505,567 \\
\hline 2012 & 505,917 & 101,968 & 219,614 & 505,917 \\
\hline 2013 & 566,595 & 158,875 & 254,637 & 566,595 \\
\hline 2014 & 559,149 & 152,054 & 249,059 & 559,149 \\
\hline 2015 & 475,175 & 67,154 & 229,566 & 475,175 \\
\hline 2016 & 402,968 & 0 & 174,269 & 402,968 \\
\hline 2017 & 313,414 & 0 & 112,777 & 313,414 \\
\hline 2018 & 239,876 & 0 & 62,704 & 239,876 \\
\hline
\end{tabular}

Source: Ministry of Labour and Social Affairs (unemployed persons), own calculations (three scenarios) 
Table 2 represents the three scenarios of ELR participants in the Czech Republic between 1995 and 2018. The column "total unemployed" stands for the average number of unemployed persons registered at Labour Offices in a given year.

In the first scenario, ELR employs all applicants over the average rate of natural unemployment ${ }^{2}$ (calculated in the related period 1995-2018). In this case, ELR would filter out the full amount of cyclical unemployment from the labour market. Under such circumstances, ELR would employ (depending on phase of economic cycle) from 0 to 159 thousand persons.

Scenario 2 is based on data on long-term unemployment. ELR employs all applicants registered at Labour Offices for longer than 12 months. In this case, ELR filters out long-term unemployment: 48 to 278 thousand persons.

Scenario 3 stands for a hypothetical situation where every unemployed person enters the ELR scheme. Under such circumstances, ELR would employ from 155 to 567 thousand persons.

\section{Figure 2: Wage cost projection (without using survey data)}

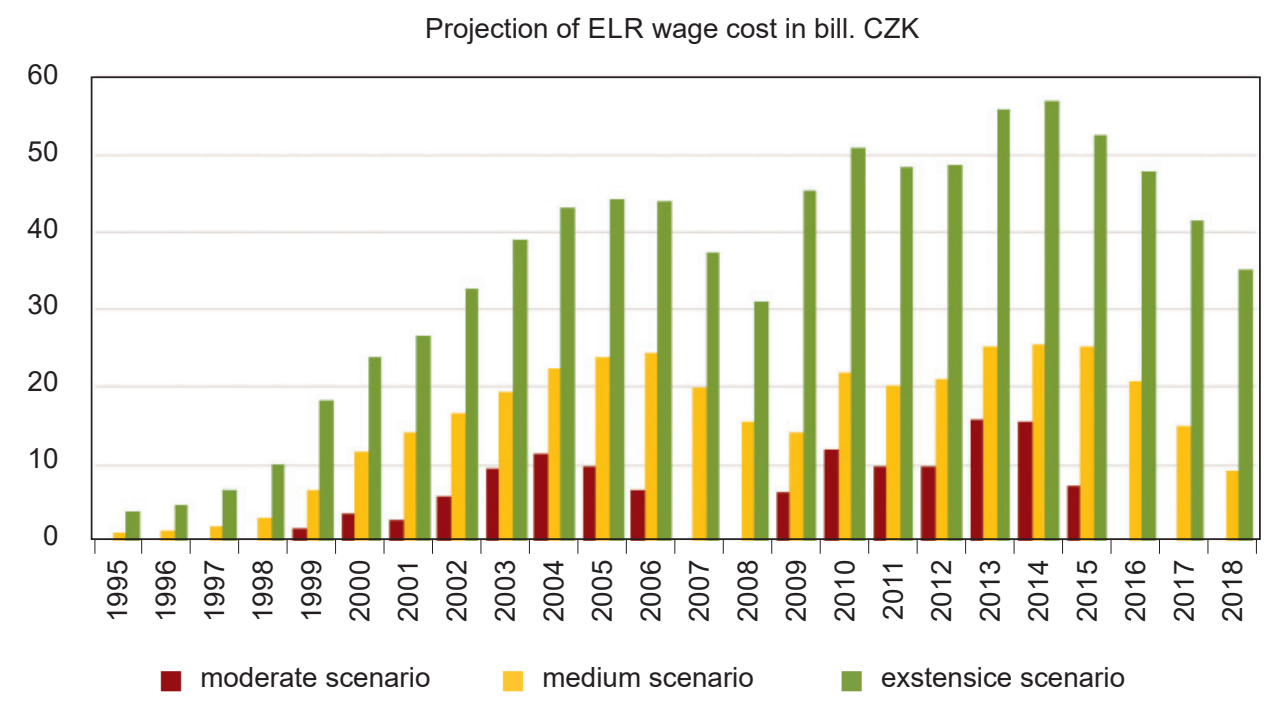

Source: Author's own calculations

2 Natural unemployment is understood as a level of unemployment that would persist if the production of a given economy was at its potential. In other words, in a situation where the cyclical part of unemployment was zero. 
Figure 2 shows possible wage costs of ELR in the period 1995-2018. The scenarios presented above and the legal minimum wages (valid in given years) were used when calculating the sums for individual years.

We can see that within a moderate scenario, there are no wage costs for years of economic boom. This is an expectable consequence of the simulation settings, as Scenario 1 only filters out cyclical unemployment. Even in years of economic downturn and unemployment peaks $(2013,2014)$, the wage costs would amount to less than 16 billion CZK. That was equal to just $0.38 \%$ of the Czech GDP and $1.33 \%$ of the state budget.

In a medium scenario, the wage costs oscillate from 1.3 (in 1995) to more than 25 billion CZK $(2013,2014)$. This means that even if all persons who suffered from long-term unemployment were given a job in the programme, the wage costs would be no more than $0.73 \%$ of the GDP or $2.59 \%$ of the Czech state budget.

The extensive scenario represents a theoretical situation in which all persons registered at Labour Offices would enter the ELR scheme. This simulation, no matter how unlikely, shows us the absolute maximum of wage costs in the programme. It varies from 4 to 57 billion CZK. In the year of the highest unemployment peak, the ELR wage costs would amount to $5.01 \%$ of the state budget and $1.41 \%$ of the Czech GDP.

From a policy-making perspective, not the highest costs, but the average costs might be important. Thanks to the wide time range of the data used, the average statistics can illustrate potential costs across the business cycle. These statistics are shown in Table 3 .

Table 3: Average annual statistics of Czech ELR (without using survey data)

\begin{tabular}{l|c|c|c|c|c}
\hline Scenario & $\begin{array}{c}\text { Average } \\
\text { participants }\end{array}$ & $\begin{array}{c}\text { Portion of total } \\
\text { employment } \\
\text { (\%) }\end{array}$ & $\begin{array}{c}\text { Average wage } \\
\text { costs } \\
\text { (billion CZK) }\end{array}$ & $\begin{array}{c}\text { Portion } \\
\text { of costs/GDP } \\
\text { (\%) }\end{array}$ & $\begin{array}{c}\text { Portion } \\
\text { of cost/budget } \\
\text { (\%) }\end{array}$ \\
\hline $\begin{array}{l}\text { Scenario 1: } \\
\text { cyclical U }\end{array}$ & 61,819 & 1.31 & 5.4 & 0.15 & 0.53 \\
\hline $\begin{array}{l}\text { Scenario 2: } \\
\text { long-term U }\end{array}$ & 186,389 & 3.92 & 15.9 & 0.45 & 1.60 \\
\hline $\begin{array}{l}\text { Scenario 3: } \\
\text { general case }\end{array}$ & 417,781 & 8.75 & 35.4 & 0.99 & 3.55 \\
\hline
\end{tabular}

Source: Author's own calculations

Table 3 presents averages for particular scenarios. We can see that between 1995 and 2018, there could be between 62 and 418 thousand ELR employees. The wage costs are relatively low. Even in the extensive scenario, when we assume that all unemployed decide to enter ELR, the average wage costs do not exceed $1 \%$ of the Czech GDP. This result is in accordance with other studies mentioned in the literature review. 


\subsection{Simulation integrating survey data}

The second part of the results takes the simple results and their scenarios and combines them with the outcomes from the survey performed.

Table 4: Estimation of ELR participants (using survey data)

\begin{tabular}{|c|c|c|c|c|}
\hline Year & $\begin{array}{c}\text { Total } \\
\text { unemployed }\end{array}$ & $\begin{array}{l}\text { ELR participants: } \\
\text { Scenario } 1\end{array}$ & $\begin{array}{c}\text { ELR participants: } \\
\text { Scenario } 2\end{array}$ & $\begin{array}{c}\text { ELR participants: } \\
\text { Scenario } 3\end{array}$ \\
\hline 1995 & 154,992 & 0 & 32,659 & 117,794 \\
\hline 1996 & 162,042 & 0 & 34,239 & 123,152 \\
\hline 1997 & 222,983 & 0 & 46,032 & 169,467 \\
\hline 1998 & 316,567 & 0 & 66,853 & 240,591 \\
\hline 1999 & 447,367 & 33,703 & 112,212 & 339,999 \\
\hline 2000 & 468,708 & 50,999 & 154,550 & 356,218 \\
\hline 2001 & 444,017 & 35,303 & 158,335 & 337,453 \\
\hline 2002 & 479,650 & 61,574 & 164,522 & 364,534 \\
\hline 2003 & 522,758 & 93,266 & 176,469 & 397,296 \\
\hline 2004 & 537,398 & 103,891 & 188,295 & 408,423 \\
\hline 2005 & 513,007 & 83,846 & 185,858 & 389,886 \\
\hline 2006 & 472,212 & 52,805 & 176,254 & 358,881 \\
\hline 2007 & 388,875 & 0 & 140,365 & 295,545 \\
\hline 2008 & 324,465 & 0 & 110,158 & 246,594 \\
\hline 2009 & 473,363 & 48,778 & 99,756 & 359,756 \\
\hline 2010 & 529,684 & 90,674 & 155,182 & 402,560 \\
\hline 2011 & 505,567 & 74,237 & 142,069 & 384,231 \\
\hline 2012 & 505,917 & 74,075 & 148,488 & 384,497 \\
\hline 2013 & 566,595 & 115,415 & 172,167 & 430,612 \\
\hline 2014 & 559,149 & 110,460 & 168,396 & 424,953 \\
\hline 2015 & 475,175 & 48,784 & 155,216 & 361,133 \\
\hline 2016 & 402,968 & 0 & 117,829 & 306,256 \\
\hline 2017 & 313,414 & 0 & 76,252 & 238,195 \\
\hline 2018 & 239,876 & 0 & 42,396 & 182,306 \\
\hline
\end{tabular}

Source: Ministry of Social Affairs (unemployed persons), own calculations (three scenarios) 
In Table 4, Scenario 1 is again based on the concept of natural unemployment. However, in this scenario, ELR does not employ all applicants over the average rate of natural unemployment, but only $73 \%$ of them (which is related to positive answers to a related question from the survey).

Similarly to Table 2, Scenario 2 is based on data on long-term unemployment. The difference is that in this case ELR does not employ all applicants registered at Labour Offices for longer than 12 months, but only $68 \%$ of them. This portion is also based on positive answers to a relevant question in the survey.

Scenario 3 stands for a hypothetical situation where $76 \%$ of all unemployed persons enter the ELR scheme. As in the previous two scenarios, this calculation is based on survey results. In this case, it is based on the survey question related to the willingness to enter ELR generally.

\section{Figure 3: Wage cost projection (using survey data)}

Projection of ELR wage cost in bill. CZK

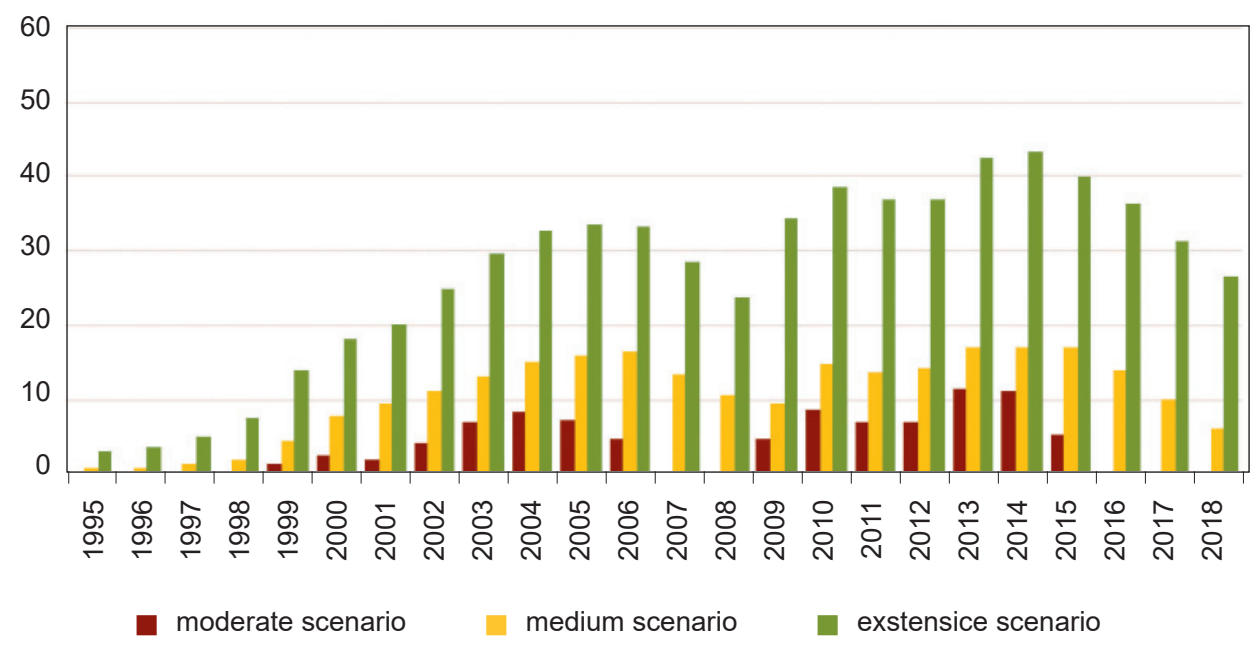

Source: Author's own calculations

Figure 3 shows possible wage costs of ELR in the period 1995-2018 after incorporating the survey data.

In Scenario 1, the total amount of resources needed for ELR would be between 0 and 11.4 billion CZK. This means that the wage costs would account maximally for $0.28 \%$ of the GDP and $0.97 \%$ of the Czech state budget. These numbers are naturally lower than in original Scenario 1, which is caused by including the survey outcomes. 
In Scenario 2, the wage costs oscillate between 0.9 and 17.2 billion CZK. These sums represent $0.05-0.41 \%$ of the GDP or alternatively $0.20-1.45 \%$ of the national budget.

Finally, in the third scenario, ELR hypothetically employs $76 \%$ of all persons registered at Labour Offices. This calculation combines the total numbers of unemployed and the general willingness to participate declared by respondents in the questionnaire. It is therefore a relatively simple and direct approach, which may be an advantage in comparison to the other scenarios. In this case, between 3.1 and 43.3 billion CZK would be needed to pay the wage costs of the ELR scheme. In relative terms, it makes $0.20-1.03 \%$ of the GDP and $0.72-3.81 \%$ of the state budget.

Again, we may be interested in the average number of participants and average costs, as in the long term the economy is naturally going through the economic cycle.

Table 5: Average annual statistics of Czech ELR (using survey data)

\begin{tabular}{l|c|c|c|c|c}
\hline Scenario & $\begin{array}{c}\text { Average } \\
\text { participants }\end{array}$ & $\begin{array}{c}\text { Portion of total } \\
\text { employment } \\
\text { (\%) }\end{array}$ & $\begin{array}{c}\text { Average } \\
\text { wage costs } \\
\text { (billion CZK) }\end{array}$ & $\begin{array}{c}\text { Portion } \\
\text { of costs/GDP } \\
\text { (\%) }\end{array}$ & $\begin{array}{c}\text { Portion } \\
\text { of cost/budget } \\
\text { (\%) }\end{array}$ \\
\hline $\begin{array}{l}\text { Scenario 1: } \\
\text { cyclical U }\end{array}$ & 44,909 & 0.95 & 3.9 & 0.11 & 0.39 \\
\hline $\begin{array}{l}\text { Scenario 2: } \\
\text { long-term U }\end{array}$ & 126,023 & 2.65 & 10.7 & 0.30 & 1.08 \\
\hline $\begin{array}{l}\text { Scenario 3: } \\
\text { general case }\end{array}$ & 317,514 & 6.65 & 26.9 & 0.75 & 2.7 \\
\hline
\end{tabular}

Source: Author's own calculations

Table 5 shows average numbers of participants and average wage costs in both absolute and relative terms. We can see that even in the extensive scenario (where ELR employs more than 300,000 persons annually), the wage costs amount to just $0.75 \%$ of the national GDP and $2.7 \%$ of the state budget.

\section{Net Costs and Overall Effects of ELR}

In this section, I estimate the net fiscal impact of the ELR programme by adding other costs (administration, equipment, etc.) and comparing them with total costs of unemployment (drop in excise tax revenue, increase in paid social security benefits and others).

\subsection{Costs of unemployment}

Unemployment represents a heavy burden for public budgets. Once an employee is dismissed, it creates several financial costs. The first is a fall in tax revenues and obligatory 
social and healthcare contributions. At the same time, new expenses from public budgets go to unemployment benefits and in some cases also to retraining courses. These activities must be administered and organized, which creates additional costs.

Apart from the abovementioned "direct" costs, public budgets are also likely to experience a fall in excise tax revenue, as unemployed people suffer from a drop in incomes.

All these factors could be specified as economic burdens, but there are also social factors accompanying the unemployment phenomenon.

Unemployed persons more often suffer from worse psychical condition (Buchtová and Šmajs, 2006), tend to social isolation and loss of "everyday habits", which may negatively affect not only their personal but also family situation (Mareš et al., 2003). According to some authors, difficulties associated with being unemployed may lead to an increase in criminality (Raphael and Winter-Ember, 2001; Edmark, 2005).

To quantify fiscal demands related to unemployment, some researchers calculate the average sum of costs per person. The team of the Research Institute for Labour and Social Affairs (hereafter "RILSA") calculated monthly costs related to one unemployed person to be 17,250 CZK (Jahoda and Godarová, 2016). According to authors from the Prague University of Economics and Business and the Unicorn College, the average monthly costs related to one unemployed person equal 21,923 CZK (Čadil et al., 2011).

\subsection{Net return on ELR}

The costs of unemployment presented in the previous section represent a potential return on ELR, as it would help public budgets avoid these expenditures.

If we consider the cited studies (Jahoda and Godarová, 2016; Čadil et al., 2011), it is obvious that costs per unemployed person exceed by far the Czech minimum wage, which was 13,350 CZK in 2019 (MoLSA, 2021b). This simple comparison is nevertheless not sufficient to discover the net effect.

When an unemployed person enters ELR, it would create more fiscal demands than just the wage. To provide the ELR jobs, operational costs would have to be included: materials, equipment, administration and others (Antonopoulos et al., 2014).

The exact portion of the operational costs is unsure and depends on the types of projects implemented. In order to calculate at least a rough estimate, we use portions suggested in the previously presented studies. In this regard, the Greek study uses a 60/40 ratio, meaning that wages would amount for $60 \%$ of the total ELR costs (Antonopoulos et al., 2014) and the study focused on Italy uses a 70/30 ratio, meaning that wages would amount for $70 \%$ of the total ELR costs (Mastromatteo and Esposito, 2017). 
I use both estimations of these portions, and both mentioned studies calculating the "costs of unemployment" to calculate the potential net effect of ELR in the Czech Republic. The results are shown in Table 6.

Table 6: Net financial effect of ELR (monthly per person)

\begin{tabular}{l|c|c|c|c|c}
\hline Study & $\begin{array}{c}\text { Average costs } \\
\text { per unemployed } \\
\text { (CZK) }\end{array}$ & $\begin{array}{c}\text { Total ELR } \\
\text { costs (70/30) } \\
\text { (CZK) }\end{array}$ & $\begin{array}{c}\text { Net ELR } \\
\text { costs (70/30) } \\
\text { (CZK) }\end{array}$ & $\begin{array}{c}\text { Total ELR } \\
\text { costs (60/40) } \\
\text { (CZK) }\end{array}$ & $\begin{array}{c}\text { Net ELR } \\
\text { costs (60/40) } \\
\text { (CZK) }\end{array}$ \\
\hline Čadil et al., 2011 & 21,923 & 19,071 & $+2,852$ & 22,250 & -327 \\
\hline $\begin{array}{l}\text { Jahoda and } \\
\text { Godarová, 2016 }\end{array}$ & 17,250 & 19,071 & $-1,821$ & 22,250 & $-5,000$ \\
\hline
\end{tabular}

Source: Author's own calculations based on cited studies

Table 6 presents both expenditures related to unemployed people and expenditures related to employing unemployed persons in the ELR programme. Expenditures related to unemployment are obtained from the cited studies and expenditures related to ELR are calculated as the minimum wage (13,350 CZK in 2019) increased by the predicted portion of operational costs.

We can see that the net monthly costs per person in the ELR scheme are in the interval from $-5,000 \mathrm{CZK}$ to $+2,852 \mathrm{CZK}$. It means that in the most optimistic case, the costs are negative. This result confirms findings from the study of Mastromatteo and Esposito (2017), which came to the same conclusion for Italy.

\section{ELR in Context of Poverty and Income Inequality}

The last section of this study focuses on the potential of the ELR scheme to reduce poverty and income inequality, which is one of its main objectives.

\subsection{ELR as instrument for reducing income poverty}

In 2018 , only $3.4 \%$ of employed persons were threatened by poverty, while it was $53.2 \%$ of unemployed (CZSO, 2018). Therefore, we could assume that the potential of the programme to reduce income poverty would be considerable. On the other hand, it depends on the level of ELR wage, which would have to be established above the poverty line to reduce the numbers of people living in poverty.

Historic data show us that the net minimum wage (which stand for the predicted ELR wage) in the Czech Republic was well below the poverty line for the last decade. 
Table 7: Long-term relationship between poverty line and minimum wage [CZK]

\begin{tabular}{l|c|c|c|c}
\hline Year & $\begin{array}{c}\text { Income } \\
\text { poverty line }\end{array}$ & $\begin{array}{c}\text { Gross minimum } \\
\text { wage }\end{array}$ & $\begin{array}{c}\text { Net minimum } \\
\text { wage }^{3}\end{array}$ & $\begin{array}{c}\text { Net minimum wage } \\
\text { minus poverty line }\end{array}$ \\
\hline $\mathbf{2 0 0 8}$ & 8,424 & 8,000 & 7,120 & $-1,304$ \\
\hline $\mathbf{2 0 0 9}$ & 9,099 & 8,000 & 7,120 & $-1,979$ \\
\hline $\mathbf{2 0 1 0}$ & 9,329 & 8,000 & 7,120 & $-2,209$ \\
\hline $\mathbf{2 0 1 1}$ & 9,420 & 8,000 & 7,120 & $-2,300$ \\
\hline $\mathbf{2 0 1 2}$ & 9,579 & 8,000 & 7,120 & $-2,459$ \\
\hline $\mathbf{2 0 1 3}$ & 9,674 & 8,500 & 7,565 & $-2,109$ \\
\hline $\mathbf{2 0 1 4}$ & 9,901 & 8,500 & 7,565 & $-2,336$ \\
\hline $\mathbf{2 0 1 5}$ & 10,220 & 9,200 & 8,188 & $-2,032$ \\
\hline $\mathbf{2 0 1 6}$ & 10,691 & 9,900 & 8,811 & $-1,880$ \\
\hline $\mathbf{2 0 1 7}$ & 11,195 & 11,000 & 9,649 & $-1,546$ \\
\hline $\mathbf{2 0 1 8}$ & 11,963 & 12,200 & 10,476 & $-1,487$ \\
\hline
\end{tabular}

Source: Czech Statistical Office and own calculations ${ }^{3}$

Table 7 shows the historic development of the gross minimum wage, net minimum wage, poverty line and their difference from 2008 to 2018. It is clear that except some special circumstances (when the employee has another income or lives in a specific kind of household), there is little space for ELR to help reduce income poverty. We can conclude, in other words, that if an unemployed person entered ELR (with a wage by definition at the level of the minimum wage), it would not help the person get above the poverty line.

\subsection{ELR as instrument for reducing income inequality}

To assess the effect of ELR on income inequality, we should compare it with its alternative. We can assume that most ELR applicants would be either unemployed or in imminent danger of losing their job, so the closest alternative is the unemployment benefit.

3 A tax reform was passed in 2008 by which a $15 \%$ tax on "super-gross" wage and a basic tax discount of 2,070 CZK were set. Net wages in this column are calculated in accordance with this legislation and with incorporation of $6.5 \%$ and $4.5 \%$ of obligatory social and health insurance contributions. 
Unemployment benefits in the Czech Republic constitute a claim to $65 \%$ of the net income from the last occupation during the first two months of unemployment. In the third and fourth month, it is lowered to $50 \%$ and further to $45 \%$ in all following months. ${ }^{4}$

If we abstract from other social security programmes, which are not directly related to one's position on the labour market, it is clear that the alternative would be a zero income after the expiry of the support period. Entering ELR would hypothetically pay off for participants from all social classes. More interesting results come from the analysis within the support period.

If we compare the hypothetical ELR wage with potential incomes related to unemployment benefits, it is clear that entering ELR would be mostly beneficial for those at the tail of the income distribution.

The differences between hypothetical ELR income and income from unemployment benefits are summarized in the following table.

Table 8: Unemployment benefits and net financial utility from entering ELR

\begin{tabular}{l|r|r|r|r|r|r|r}
\hline $\begin{array}{l}\text { Income } \\
\text { distribution }\end{array}$ & $\begin{array}{c}\mathbf{5 t h} \\
\text { percentile }\end{array}$ & $\begin{array}{c}\text { 1st } \\
\text { decile }\end{array}$ & $\begin{array}{c}\text { 1st } \\
\text { quartile }\end{array}$ & Median & $\begin{array}{c}\text { 3rd } \\
\text { quartile }\end{array}$ & $\begin{array}{c}\text { 9th } \\
\text { decile }\end{array}$ & $\begin{array}{c}\text { 95th } \\
\text { percentile }\end{array}$ \\
\hline $\begin{array}{l}\text { Higher incomes } \\
\text { than }\end{array}$ & $5 \%$ & $10 \%$ & $25 \%$ & $50 \%$ & $75 \%$ & $90 \%$ & $95 \%$ \\
\hline Gross wage & 12,307 & 14,106 & 19,674 & 26,843 & 35,550 & 48,718 & 62,227 \\
\hline Net wage & 10,550 & 11,789 & 15,625 & 20,565 & 26,564 & 35,637 & 44,944 \\
\hline ELR net wage (2017) & 9,649 & 9,649 & 9,649 & 9,649 & 9,649 & 9,649 & 9,649 \\
\hline $\mathbf{6 5 \%}$ of net wage & 6,857 & 7,663 & 10,157 & 13,367 & 17,267 & 23,164 & 29,214 \\
\hline $\mathbf{5 0} \%$ of net wage & 5,275 & 5,895 & 7,813 & 10,282 & 13,282 & 17,818 & 22,472 \\
\hline $\mathbf{4 5 \%}$ of net wage & 4,747 & 5,305 & 7,031 & 9,254 & 11,954 & 16,037 & 20,2252 \\
\hline
\end{tabular}

Source: Czech Statistical Office and own calculations

The table above shows the income distribution in the Czech Republic in 2017, net ELR/minimum wage (which is the same for all groups) and unemployment benefits (calculated separately for different income percentiles).

4 Maximum period of continuous receiving of unemployment benefits is 5 months for those younger than 50,8 months for those aged between 50 and 55 and 11 months for those aged more than 55 . 
Entering the programme would instantly pay off to those who are in the $5^{\text {th }}$ percentile and even in the $1^{\text {st }}$ decile. After two months, entering ELR would be beneficial to all within the $1^{\text {st }}$ quartile and after four months, even to those with (up to) median income.

Specific sums in the table may differ in time, but the general effect of ELR is clear: entering the programme would first pay off for the lowest income groups and later it would become beneficial for the wider lower-middle class. Members of the high-income class would not have a financial incentive to enter ELR through all of the support period.

We may conclude that the ELR programme could help increase income of lower classes while it would have no direct effect on higher-income classes.

\section{Conclusion}

This study analysed potential impacts of implementing an ELR programme in the Czech Republic. The evaluation criteria were in accordance with the most frequently stated objectives of ELR: boosting of employment, reduction of poverty and income inequality. At the same time, financial demands of the programme were calculated.

The analysis was based on historic data from Labour Offices and on a survey investigating the willingness to enter ELR under different circumstances.

In general, $76 \%$ of respondents would be willing to enter the programme. On average, the ELR programme could employ 45 to 318 thousand participants with annual wage costs between 3.9 and 26.9 billion CZK. This means that the annual wage costs are below $1 \%$ of the Czech GDP in all the calculated scenarios.

The net financial costs of employing a person in the programme vary from $-5,000$ CZK to $+2,852$ CZK monthly. In other words, the final bill for introducing ELR could be rather low, or even negative. These results are in accordance with previously published studies on ELR.

There is still much room for future research, for example deeper analysis of ELR as an instrument for mitigating economic recessions, or research focused on other countries. Nevertheless, the research made so far definitely suggests that the Employer of Last Resort is an instrument worthy of both policymakers' and economists' attention.

\section{References:}

Antonopoulos, R., Adam, S., Kim, K., et al. (2014). Responding to the Unemployment Challenge: A Job Guarantee Proposal for Greece. New York: Levy Economics Institute of Bard College. ISBN 978-1-936192-40-3.

Buchtová, B., Šmajs, J., Boleloucký, Z. (2013). Nezaměstnanost - 2. přepracované a aktualizované vydání. Praha: Grada Publishing. ISBN 978-80-247-4282-3. 
CZSO (2018). Osoby ohrožené chudobou v letech 2013-2018. Prague: Czech Statistical Office. Available at: https://www.czso.cz/documents/10180/91839453/1600211919.pdf/ cf53b95c-a879-4aef-9cde-bf6967884d56?version $=1.0$

CZSO (2019b ). Příjmová chudoba ohrožuje necelou desetinu obyvatel. Prague: Czech Statistical Office. Available at: https://www.czso.cz/csu/czso/ prijmova-chudoba-ohrozuje-necelou-desetinu-obyvatel

CZSO (2020). Výběrové šetření pracovních sil (VŠPS). Prague: Czech Statistical Office. Available at: https://www.czso.cz/csu/vykazy/vyberove_setreni_pracovnich_sil

Čadil, J., Pavelka, T., Kaňková, E., et al. (2011). Odhad nákladů nezaměstnanosti z pohledu veřejných rozpočtů. Politická ekonomie, 59(5), 618-637, https://doi.org/10.18267/j. polek.811

Edmark, K. (2005). Unemployment and Crime: Is There a Connection? The Scandinavian Journal of Economics, 107(2), 353-373, https://doi.org/10.1111/j.1467-9442.2005.00412.x

EUROSTAT (2007-2018). Total Unemployment Rate. Luxembourg: Statistical office of the European Union. Available at: https://ec.europa.eu/eurostat/web/ products-datasets/-/tps00203

Godin, A. (2012). Guaranteed Green Jobs: Sustainable Full Employment. Levy Economics Institute of Bard College. New York Working Paper No. 722, https://doi.org/10.2139/ ssrn.2060326

Jahoda, R., Godarová, J. (2016). Odhad nákladů veřejných rozpočtů vynakládaných na jednoho nezaměstnaného. Výzkumný ústav práce a sociálních věcí - Research Institute for Labour and Social Affairs. Prague Working Paper No. 506.

Kregel, J. (2009). Mobilizing Domestic Resources: Employer of Last Resort as a National Development Strategy to Achieve the Internationally Agreed on Development Goals. International Journal of Political Economy, 38(3), 29-57, https://doi.org/10.2753/ ijp0891-1916380303

Mareš, P., Sirovárka, J., Vyhlídal, J. (2003). Dlouhodobě nezaměstnaní - životní situace a strategie / The Long-term Unemployed - Living Conditions and Strategies. Sociologický Časopis / Czech Sociological Review, 39(1), 37-54, https://doi.org/10.13060/00380288.20 03.39.1.04

Mastromatteo, G., Esposito, L. (2017). Banking on ELR: How Hyman Minsky's Ideas Can Help Tackle Unemployment. Journal of Economic Issue, 51(3), 635-650, https://doi.org/10.108 $0 / 00213624.2017 .1353873$

MF CR (2018). Státní rozpočet v kostce - 2018. Prague: Ministry of Finance of the Czech Republic. Available at: https://www.mfcr.cz/cs/o-ministerstvu/vzdelavani/ rozpocet-v-kostce/statni-rozpocet-v-kostce-2018-31944

Minsky, H. P. (1965). The Role of Employment Policy. Hyman P. Minsky Archive. Paper No. 270. Available at: https://digitalcommons.bard.edu/hm_archive/270 
MoLSA (2020). Analýza vývoje zaměstnanosti a nezaměstnanosti v roce 2019. Prague: Ministry of Labour and Social Affairs of the Czech Republic. Available at: https://www.mpsv.cz/documents/20142/1736728/Anal\%C3\%BDza+-+text. pdf/7f60fc4c-1ce3-b887-94e7-493d2dd1869c

MoLSA (2021a). Statistiky - nezaměstnanost. Prague: Ministry of Labour and Social Affairs of the Czech Republic. Available at: https://www.mpsv.cz/web/cz/nezamestnanost

MoLSA (2021b). Přehled o vývoji částek minimální mzdy. Prague: Ministry of Labour and Social Affairs of the Czech Republic. Available at: https://www.mpsv.cz/ prehled-o-vyvoji-castek-minimalni-mzdy

OECD (1995-2018). Long-term Unemployment Rate. Paris: Organization for Economic Cooperation and Development. Available at: https://data.oecd.org/unemp/long-termunemployment-rate.htm

Raphael, S., Winter-Ember, R. (2001). Identifying the Effect of Unemployment on Crime. The Journal of Law and Economics, 44(1), 259-283, https://doi.org/10.1086/320275

Tcherneva, P. (2003). Job of Income Guarantee? University of Missouri - Kansas City. Kansas City Working Paper No. 29 [Retrieved 2021-06-08] Available at: http://citeseerx.ist.psu. edu/viewdoc/download?doi=10.1.1.423.5181\&rep=rep1\&type=pdf

Tcherneva, P. R., Wray, L. R. (2005). Employer of Last Resort: A Case Study of Argentina's Jefes Program. [Retrieved 2021-06-08], http://doi.org/10.2139/ssrn.1010145

Wray, L. R. (2009). The Social and Economic Importance of Full Employment. Levy Economics Institute of Bard College. New York Working Paper No. 560, https://doi.org/10.2139/ ssrn.1394467 